\title{
Calculating the Unit Costs by the Learning Activity- Based Costing in Technology and Engineering Vocational School
}

\author{
Yayat Yayat* \\ Department of Mechanical Engineering Education \\ Universitas Pendidikan Indonesia \\ Bandung, Indonesia \\ *yayat_jptm@upi.edu
}

\author{
Nanang Fattah \\ Department of Management \\ Universitas Pendidikan Indonesia \\ Bandung, Indonesia
}

\author{
Danny Meirawan \\ Department of Civil Engineering Education \\ Universitas Pendidikan Indonesia \\ Bandung, Indonesia
}

\begin{abstract}
The aim of this study is at obtaining information about the amount of operational costs needed by a student to complete vocational education in a Vocational High School. Learning Activity-Based Costing (LABC) is a new method in calculating costs in the education sector. Calculation the education costs currently used traditional financing methods with the number of students as a driver to allocate costs. This observational descriptive study used a single case study method to determine the operational unit costs of the student in the Mechanical Engineering Expertise Program in the State Vocational High School in the fields of Technology and Engineering Expertise. The results showed that the use of LABC was able to show more detailed and comprehensive cost information. Calculation of costs using $\mathrm{LABC}$ results in higher operational unit costs per student compared to existing operational unit costs.
\end{abstract}

Keywords: learning activity-based costing, vocational education, unit cost

\section{INTRODUCTION}

Vocational Education is the type of education which provides individuals with skills, knowledge and attitudes for effective employment in specific occupation [1] or for employment in recognized occupation [2], because their students are prepared to work [3]. Vocational education can be interpreted as education for work, so that it occupies a strategic side in preparing the workforce trained and ready to work (ready for use). The implementation of vocational education must be focused on the process of mastering the knowledge, attitudes and skills for work. Students in vocational education must have real experience according to their field of expertise as a provision for work. Vocational education students must have real experience according to their area of expertise as a provision for work. Required equipment in accordance with existing equipment in the world of work and of course the price is expensive Therefore, vocational education is expensive education.

Cost is one aspect of the educational input component (instrumental input) which is very important, because it also determines the realization of quality education. Education will be of high quality if supported by the availability of adequate costs (according to standards). In the educational institutes, cost is defined as a monetary measure that represents the sum of wealth invested in resources to provide services and in turn gain revenues or fulfill social needs [4]. Therefore, cost needed in the implementation of education must be planned and calculated carefully in order to meet the adequacy standard. At present, the calculation of education costs still uses Conventional Systems or Traditional Costing (TC). The Traditional Costing (TC) only has the single indirect-cost pool and arbitrary allocation cost bases [5]; inadequacy to provide the needed change in business environment [6]; do not display significant distortions in overheads, which leads to overcosting of activities [4]; to assign cost directly to products, rather than to activities and allocates the indirect costs to products or services arbitrarily using one cost driver [7]; and does not give information regarding the reasons of cost created [8]. Some weaknesses that are owned by the traditional system, causing the calculation results in determining the cost to be inaccurate and financial decisions are ineffective. The education sector lacks data that can help minimize overhead costs and thus requires more accurate cost analysis [4]. Among the issues in the existing accounting system, the unsuitability of the criteria allocating indirect costs was found to be most important [4].

Therefore, new methods are needed in calculating the cost of education to resolve lack of in traditional/conventional systems. This is Activity-Based Costing (ABC) or Learning Activity-Based Costing (LABC). The Activity-Based Costing 
(ABC) is designed to solve the problem of overhead cost allocation by giving more accurate information on costs [6]. $\mathrm{ABC}$ is a costing methodology that identifies activities in an organization and assigns the cost of each activity with resources to all products and services according to the actual consumption by each [9]. Activity based approach has been identified as the strategic costing tool since it could improve the conventional costing by establishing direct linkages between the activities performed and the output produced [10].

$\mathrm{LABC}$ is the development of the $\mathrm{ABC}$ concept, so that between $\mathrm{ABC}$ and $\mathrm{LABC}$ have similarities, which are both a method of calculating costs based on activity. The cost calculation using the LABC focuses on educational activities carried out at school. Educational institutions must be able to identify all the costs of educational activities and those activities that have added value and not. Educational activities in educational institutions consist of main activity and supporting/managerial activity. Academic activity is learning activities carried out in schools (classrooms, laboratories, studios, and workshops) as well as outside the school/in industry in the form of Industrial Practices. The supporting activities are managerial activities in the administration of education.

The use of $\mathrm{ABC}$ in educational institutions provides several advantages such as: (a) can help educational institutes acquire detailed costing data and discern possible hidden costs that they may have previously been unaware of [4]; (b) improves information visibility that enable the university management to understand the link between costs and activities and also identify between value added and non value added activities [10]; (c) providing detailed cost information to administration for further analysis and proper decision making [8], and (d) the results indicate that activity-based costing system provides optimized and better information about the cost of the organization's managers [11].

The study aims to reveal information about the average of operating unit costs required a student to complete vocational education in the Mechanical Engineering Expertise Program at the State Vocational High School. The focus of the discussion is on all activities in education (academic and supporting). The calculated cost component are components of personal and non-personal costs both direct and indirect. This study are focused on personal and non-personal operational costs, both directly and indirectly.

\section{METHODS}

This research is an observational descriptive study with a quantitative approach. The population was teachers in the Mechanical Engineering Expertise Program in the State Vocational High School 6 Bandung. Meanwhile 19 respondents were selected as research samples by purposive random sampling. The data collection used questionnaire and documents. Then, data were analyzed descriptively using the Learning Activity-Based Costing approach with stages like in Figure 1.

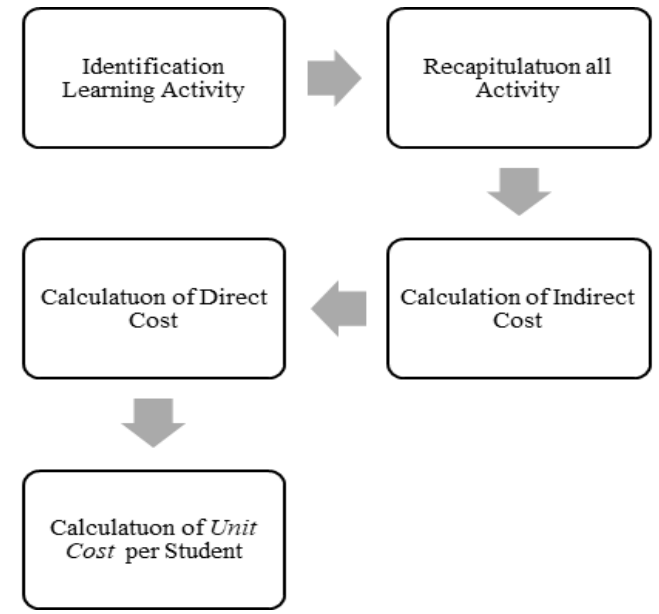

Fig. 1. Data analysis stage.

\section{RESULTS AND DISCUSSION}

\section{A. Identification of Activity and Recapitulation}

These activities were grouped consist of learning activities (semesters 1 to 6), final examination activities, and counseling $\&$ student affairs. The learning activities consist of theoretical learning activities, practical learning activities, preparations to exam questions, examination, and result exam correction. Especially for semesters 3 and 4, there are off-campus learning activities (Industry). The final examination activities consist of national exam preparation activities, competency tests, school examinations, national examinations, and TOEIC / TOEFEL tests. As for counseling \& student affairs consists of registration activities, period of the awareness school area, pathfinder orientation, student IQ tests, guidance and counseling, extra-curricular activities, development of religiousness, development of student organizations, upgrading student's competences, school health, and graduation.

\section{B. Indirect Cost (IC)}

The IC calculated in this study are only: (1) operational costs, (2) maintenance costs, and (3) institutional development costs. The results of IC calculation are in the Figure 2. 


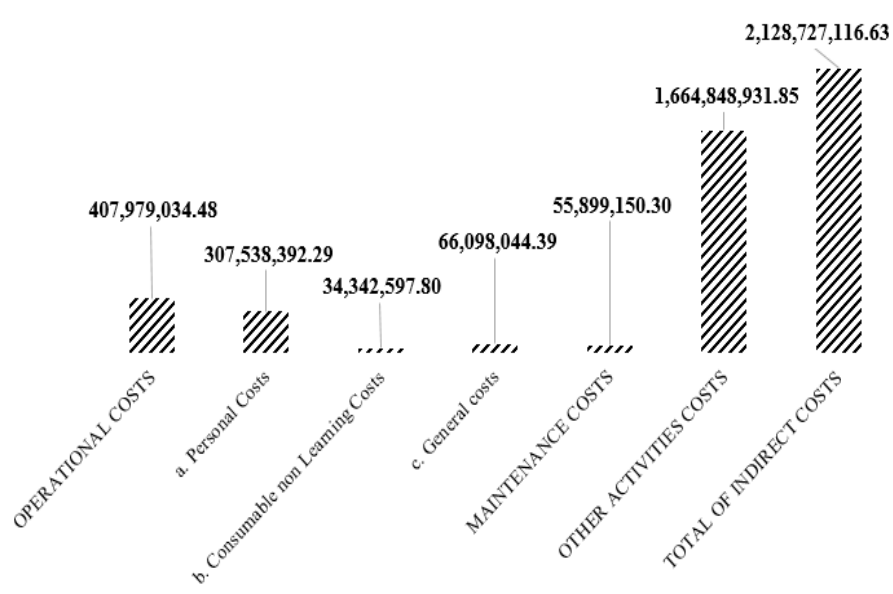

Fig. 2. Indirect Cost (IC).

\section{Direct Cost $(D C)$}

Direct Cost (DC) is a cost that directly related to the learning process. The learning process at Vocational School is conducted for 6 semesters. The types of activities in each semester are relatively the same. It is teaching and learning process activities and examination process (middle and final semester exams). The teaching and learning process for 2 th and 3 th semester, is not only carried out in school but also in industry. Likewise with learning process in the 6th semester, the exam process is not only middle and final semester exams, but is added with the final school examination, competency test, and national examination. These activities are the primary activity categories. The DC calculation was only personal operational costs (teacher salaries) and learning materials and consumables. The calculation results show that the total direct cost needed by students for 3 years are IDR 50,867,761.38 consist of the personal costs of IDR 28,558,710.62, and learning materials and consumables costs of IDR 22,309,050.75 (Figure 3).

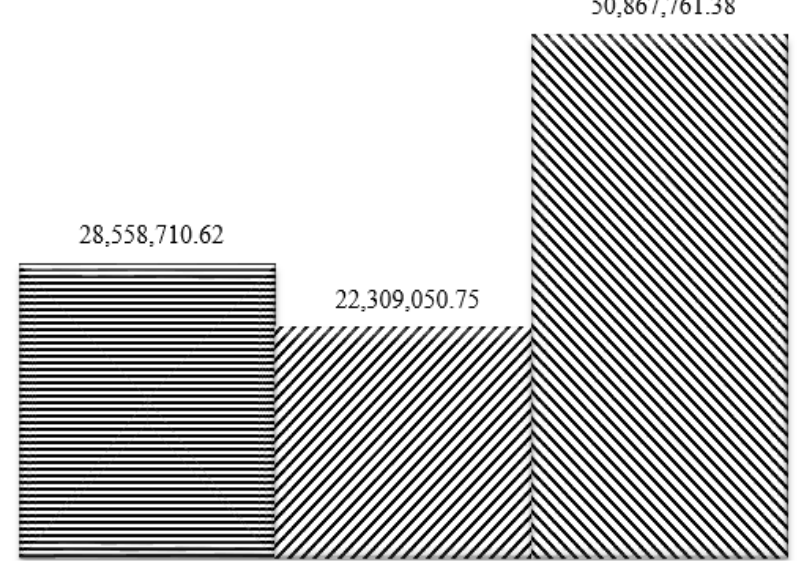

ÐPERSONAL COSTS $\triangle$ CONSUMABLE COSTS $\triangle$ TOTAL DIRECT COSTS

Fig. 3. Direct Cost (DC).

\section{Unit Cost (UC)}

Unit cost per student is the cost required by a student to complete vocational education in the Mechanical Engineering Expertise Program in Vocational School consists of direct and indirect costs. The calculation results show that the total unit costs per student for 3 years are IDR 63,273,560.42 or IDR $21,091,186.81$ per year or IDR $10,545,593.40$ per semester. The total cost consists of direct costs are IDR 50,867,761.38 and indirect costs are IDR 12, 405, 799.04. The total unit costs per student and for each semester in detail can be show in the Figure 4 and Figure 5.

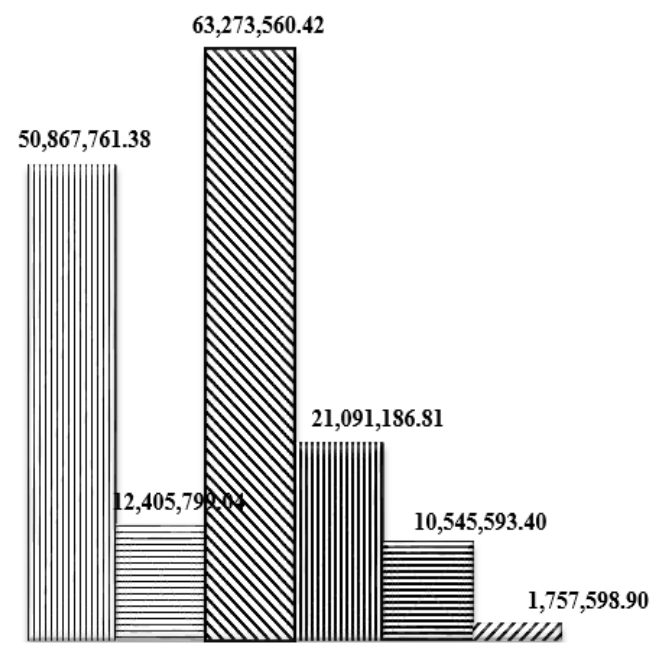

WTOT. DIRECT COST $\exists$ TOT. INDIRECT COST $\quad$ QTOT. UNIT COST IIUNIT COST/YEAR EUNTT COST/SEMESTER AUNIT COST/MONTH

Fig. 4. Total unit cost per student.

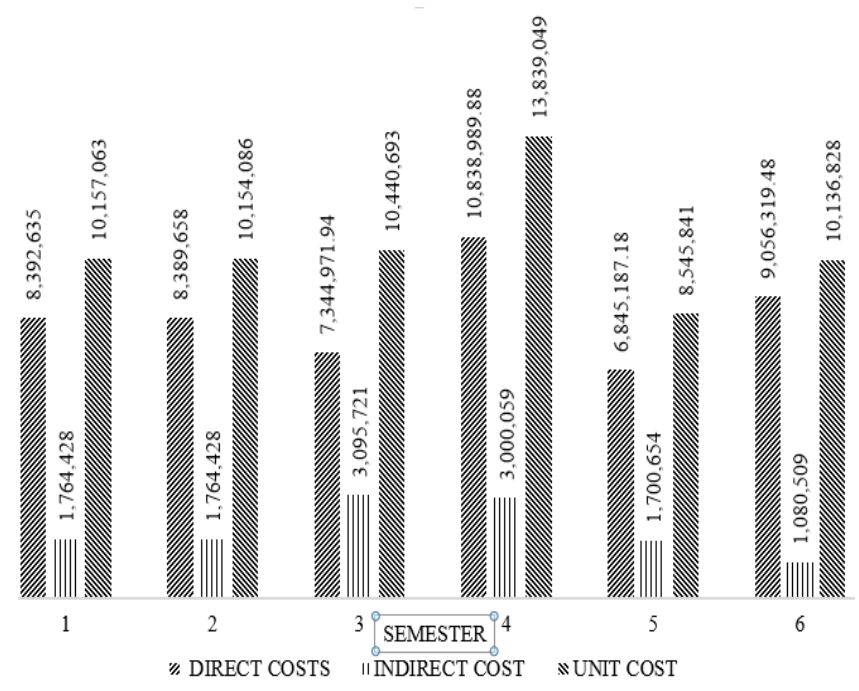

Fig. 5. Unit cost per student per semester.

\section{CONCLUSION}

This study revealed the amount of operational costs needed by a student to complete a vocational education program in the 
[3] O.O. Kennedy, "Philosophical and Sociological Overview Of Vocational Technical Education In Nigeria". International Journal of Academic Research in Business and Social Sciences, Vol. 1, Special Issue. P. 167-175. 2011.

[4] J. Sorros, A. Karagiorgos, N. Mpelesis, "Adoption of Activity-Based Costing: A Survey of the Education Sector of Greece". International Advances in Economic Research, 23(3). P. 09-320. 2017.

[5] Y.I. Lou, H.C. Wang, J.S. Lan, "Design and Implement the ActivityBased Costing in Taiwan Firm". IOSR Journal of Business and Management (IOSR-JBM) e-ISSN: 2278-487X, p-ISSN: 2319-7668. Volume 19, Issue 1. Ver. VII, PP 41-46. 2017.

[6] A.P. Egbunike, N.B. Ijeoma, C.G. Ebubeogu, "The Use of Activity Based Costing and Balance Score Card for Strategic Performance Measurement: Perception of Chartered Accountants in Anambra State, Nigeria”. American Journal of Economics, Finance and Management Vol. 1, No. 3, 2015, pp. 211-222. 2015.

[7] E.K. Oseifuah, "Activity Based Costing (ABC) In The Public Sector: Benefits And Challenges". Problems And Perspectives In Management, 12(4-2). 2014.

[8] A. Vazakidis, I. Karagiannis, A. Tsialta, "Activity-Based Costing in the Public Sector”. Journal of Social Science 6(3), Pp. 376-382. 2010.

The author would like to thank all those who have helped in the conduct of this research, especially the principal, the deputy principals, all administrative staff, and all the teachers who have provided some information for the author's needs.

\section{REFERENCES}

[1] J.L. Oviawe, R. Uwameiye, and P.S.O. Uddin, "Bridging Skill Gap to Meet Technical, Vocational Education and Training School-Workplace Collaboration in the 21st Century". International Journal of Vocational Education and Training Research, 3(1): 7-14. 2017.

[2] Ukachi and Ejiko, "Importance Of Vocational Technical Education In Present Day Nigeria Economy”. Global scientific journal. Volume 6, Issue 8, pp. 530-534. 2018.
[9] D. Kannaiah, "Activity Based Costing (ABC): Is It a Tool for Company to Achieve Competitive Advantage?" International Journal of Economics and Finance; Vol. 7, No. 12, p. 275-281. 2015.

[10] A.M. Amir, S.M. Auzair, R. Maelah, A. Ahmad, "Determination Of Educational Cost In Public University - A Modified Activity Based Approach". Journal of Social Sciences Vol. 2. No. 2. March 2012. pp. $34-48.2012$.

[11] A. Ahadi and S.F. Azar, "The study of the possibility of using activitybased costing system (ABC) (Case Study: General Directorate of Roads and Urban Development of East Azerbaijan Province.)" International Academic Journal of Accounting and Financial Management Vol. 3, No. 6, 2016, pp. 1-8. 2016. 